\title{
WEB-ENHANCED COURSE BASED ON PROBLEM-BASED LEARNING (PBL): DEVELOPMENT OF INTERACTIVE LEARNING MEDIA FOR BASIC PHYSICS II
}

\author{
Rahma Diani*1, Yuberti ${ }^{2}$, M. Ridho Syarlisjiswan ${ }^{3}$ \\ 1, 2,3 Physics Education Department, Universitas Islam Negeri Raden Intan Lampung, Indonesia. \\ *Correspondence address: rahmadiani@radenintan.ac.id
}

Accepted: January 29 ${ }^{\text {th }}$ 2018. Approved: April 19 ${ }^{\text {th }}, 2018$. Published: April $28^{\text {th }}, 2018$

\begin{abstract}
This research aims to develop an active learning media in the form of Web-Enhanced Course. This research and development research follows the development steps of Borg \& Gall. Data collection instruments used were validation sheets and questionnaires. The assessments' average score for the feasibility of the product from the material experts is $84.83 \%$, from media experts is $81.76 \%$, and informatics experts are $83.61 \%$ in the very feasible category. Furthermore, the percentage of the results of small-group testing is $76.44 \%$ and for field-testing is $82.97 \%$. Thus, the developed product is suitable to be used as a media for physics learning. The web is developed using the Problem-Based Learning (PBL) for the Basic Physics II subject.
\end{abstract}

() 2018 Physics Education Department, UIN Raden Intan, Lampung, Indonesia

Keywords: interactive, physics learning media, problem-based learning model, web-enhanced course.

\section{INTRODUCTION}

The information and communication technology is developing rapidly. One of the fields that are impacted significantly is the field of education. To keep up with the rapid technological development, education must have a great interest in keeping up with technological developments (Asyhari \& Diani, 2017) As stated in the Law of the National Education System Number 20 of 2003 that education is a process to help humans develop their potential so that they are able to face every change and make students think actively and creatively (Amri, 2014). If the students are able to think creatively, they will be able to solve problems appropriately (Antomi Saregar, Latifah, \& Sari, 2016).

As we know that men are the most perfect and noble being, Allah the Almighty blesses them with mind and though, so that humans will be able to work creatively, to produce science and technology in their lives (Yuberti, 2015)
The Qur'an provides a lot of information about science and technology proven through amazing studies and experiments. It is indeed the will of Allah to all beings to submit to His command. Science and technology explains the phenomenon of the universe and the universe itself proves the truth of the Qur'an which is interpreted consistently and does not conflict with our knowledge (Al-zindani., \& Aziz, 1997).

Along with the development globalization era which is characterized by rapid production and usage of information and technology, the conception of the implementation of learning has shifted toward the efforts to realize modern learning. Basically, the modern characteristics have previously been achieved in the development of education and learning, but it is still in the level of software intelligence (Habibi \& Kurniawan, 2014), the world of education is always moving forward dynamically especially to create interesting, 
interactive, and comprehensive media, methods and educational materials. Therefore our education sector must be able to utilize information and technology to develop electronic media-based education or known as e-education (Habibi \& Kurniawan, 2014).

Etymologically, the word media comes from the Latin word and is the plural form of the word medium which literally means intermediary or introduction. Thus, the media is a vehicle for distributing learning information or channeling messages (Arsi \& Febrianti, 2014; Gunawan, 2014). The internet has become the pioneer of the technological revolution (Sutedjo, 2002). The Internet is a type of media that can create two-way or more online interactions. The internet is a huge force. An incredible number of users making the internet as an effective and multi-purpose tool (Hidayatullah \& Kawistrara, 2017). As for Indonesia, according to data released by APJII (Indonesian Internet Service Users Association), Internet users in 2012 amounted to 63 million people. While the growth of internet users in 2016 reached 132.7 million people from the total population of 256.2 million people (APJII, 2016).

Based on these data, this media is increasingly popular to be used to develop learning activities in schools, universities, or courses because, in addition to being interactive, this media is connected to the global network so that the access range is very widespread throughout the country (Habibi \& Kurniawan, 2014). Indonesia ranks second in terms of the growth of internet usage in the world up to November 2015 which reached 88.1 million people or around $34 \%$ of the total population of Indonesia (Irwandani, 2016).

There are three forms of internet learning systems that are worth considering as the basis for developing a learning system using the internet, namely web courses, web-centric courses, and web-enhanced courses (Alfath, Ellianawati, \& Sukisno, 2013).

The web course is the use of the internet in educational activities. All educational activities are carried out through the internet such as teaching materials, discussions, assignments, etc so that they no longer need do the activities face-to-face. The web-centric course is similar to web courses. However, in the web-centric course, there are face-to-face activities between lecturers and students. Face-to-face activities contain discussions about the material that has been learned through the internet. The web-enhanced course is also known as the web lite course where the main activity is face to face. The internet is only a mean to provide enrichment. In this case, the lecturer must have the ability to recommend relevant learning material sources and are required to master information seeking techniques (Alfath et al., 2013).

Rapid technological development can be responded to by renewing the use of technology in the learning process (Antomi Saregar, 2016) and mastering scientific concepts, including Physics. Physics is a scientific discipline that has its own characteristics compared to other scientific disciplines (S.Ramos, B.Dolipas, \& B.Villamor, 2013). In Physics learning, concept understanding is highly emphasized (Ulya, 2013). Mastery of concepts and ability to solve Physics learning problems is one aspect in measuring the improvement of students' learning outcomes in order to realize quality learning that can be supported by using computer assistance (Doyan \& Sukmantara, 2014). Therefore, problemsolving in scientific disciplines requires scientific methods (A. Saregar \& Sunarno, 2013).

Through this media, the students can actively learn independently by only accessing the website through computer screens that are connected to the internet 
network (Habibi \& Kurniawan, 2014). Computers connected to the internet network will provide web services that function to help students and lecturers in the learning process. The use of the web is expected to make it easier for the students to understand abstract Physics material, re-learn in the difficult part of the material, and get reinforcement by reading learning resources such as electronic books, articles, and practice questions prepared by the lecturers (Doyan \& Sukmantara, 2014)

Web-based learning media or elearning which is now becoming very popular because of its flexibility and effectiveness is a way of delivering learning material via the internet that can be accessed anytime and from anywhere. The presence of e-learning can be a new hope and a solution to overcome the problems of education and learning (I. Wahyudi, 2017). The web can be used by students as a means to get Physics material whenever and wherever they need it or as a medium for discussion and practice. In addition, this study will also develop an existing web-based interactive Physics learning media by fulfilling the principles of media development (Putri, 2015).

The problem-based Learning model is a model of learning that requires students to develop thinking skills, problemsolving and intellectual skills, foster collaboration capabilities, and developing social attitudes. This model designs problems that require the students to gain important knowledge, make them proficient in solving problems, have their own learning strategies, and have the skills to participate in group activities. The Problem-Based Learning model is expected to provide opportunities for the students to be able to improve their scientific work skills (BS Wahyudi, 2014).

The observation found out that lecturers were still using printed media or printed books in carrying out the learning process which requires considerable time, consequently, the lecturers did not maximize the time in delivering material that affects students. The material provides by the researchers here is the Basic Physics II subject of electricity and electric field. Developing a physics learning media based on Web-enhanced courses with Problem-Based Learning model can be done as an alternative in learning. The support of internet network, infrastructure, and facilities at the Physics Education Department and the lecturers and students' ability to use computers is expected to facilitate the students in understanding the physical material (Doyan \& Sukmantara, et al 2014).

The results of the interview show that there were several problems that exist in online-based learning media in the Physics Education Department, namely, there are still many students who do not know the existence of an interactive learning system in the form of interactive physics learning media based on Webenhanced courses with Problem-Based Learning (PBL ) model.

Based on the results of the interview, the researchers developed an interactive Physics learning media in the form of web-enhanced course with ProblemBased Learning model as a mean of online learning media for students to accommodate their need to be more mobile and effective. To know the product's assessment criteria from material experts, media experts, and informatics experts. As well as to know the students' responses in small-group testing and field-testing related to the attractiveness and feasibility of the developed product.

\section{METHOD}

This study employed Research and Development method. According to Gay, Mills, da Airasian in the field of education, the main goal of research and 
development is not to formulate or test the theory, but to develop products that can be used effectively (Emzir, 2015). The Research and Development procedures were guided by the instructional media development design by Borg and Gall. The final product is a web-based interactive Physics learning media of web-enhanced course with ProblemBased Learning (PBL) model in Basic Physics II course.

The development was done through the Research and Development method. The development model used in this study was from the Borg and Gall model in Sugiyono, namely: 1). Potential and Problems, 2). Data collection, 3). Product design, 4). Design validation, 5). Design revision, 6). Product testing, 7). Product revision, 8). Field testing, 9). Product revision, 10). Dissemination.

This study limited the steps of the development from ten steps to seven steps because of the time available and limited opportunities. Research subjects for small-group testing were ten second semester students of the Physics Education Department of UIN Raden Intan Lampung. Field-testing were conducted to sixty second semester students of the Physics Education Department of UIN Raden Intan Lampung and the second-semester students of the Physics Education Department of the University of Lampung. Research data was collected using expert validation sheets and student response sheets and the data analysis was done using a Likert scale.

Data analysis was done using the following formula:

$$
x_{i}=\frac{\sum S}{S_{\max }} \times 100 \%
$$

$$
\begin{aligned}
& \text { Description: } \\
& S_{\max }=\text { Maximum score } \\
& \sum S=\text { score } \\
& x_{i}=\text { Feasibility score for each } \\
& \quad \text { aspect (Sugiono, 2013) }
\end{aligned}
$$

The questionnaire used to investigate the responses toward the use of webenhanced course interactive Physics learning media with Problem-Based Learning model (PBL) was in accordance with the content of the question. The interpretation of the assessment results of the media expert, subject matter experts, and Informatics experts from alphabetical into numerical form folows the following guideline:

Table 1. Scoring Norm

\begin{tabular}{cc}
\hline Category & Score \\
\hline (Excellent) & 5 \\
\hline$($ Good $)$ & 4 \\
\hline (Moderate $)$ & 3 \\
\hline$($ Low $)$ & 2 \\
\hline$($ Bad $)$ & 1 \\
\hline
\end{tabular}

The students were given a questionnaire to investigate their responses toward the attractiveness of the web-enhanced course interactive physics learning media with Problem-Based Learning model (PBL). To know the final score of the questionnaire, the researchers used mean item analysis by counting the feasibility score divides by the number of statements.

The results of the percentage score obtained from the research were interpreted using the following criteria:

Table 2. The feasibility score of the learning media

\begin{tabular}{cc}
\hline $\begin{array}{c}\text { The Feasibility Score of } \\
\text { the Learning Media }\end{array}$ & Criteria \\
\hline $0-20 \%$ & Not feasible \\
\hline $20.01 \%-40 \%$ & Less feasible \\
\hline $40.01 \%-60 \%$ & Quite feasible \\
\hline $60,01 \%-80 \%$ & Feasible \\
\hline $80.01 \%-100 \%$ & highly feasible \\
\hline
\end{tabular}

\section{RESULT AND DISCUSSION}

The aim of this research is to develop an interactive Physics learning media in the form of Web-Enhanced Course with Problem-Based Learning model (PBL) in the Basic Physics II course. The developed product is potentially useful to 
minimize problems in the classroom where the lecturers still use printed media or printed books in carrying out the learning process that requires quite a lot of time, resulting in the less optimum time in delivering material that affects students. In this stage, the important thing to do was to analyze the needs of learning evaluation of the developed product through unstructured interviews with the lecturers of Physics Education UIN Raden Intan Lampung. In the classroom during the learning process, the teachers were still using printed media which was very time consuming and was not conducive so that the material that must be explained cannot be delivered appropriately. The students found it difficult when working on questions given by the lecturer during the evaluation.

Next is the data collection. Data collection is very important to know the needs of lecturers and students toward the developed product. The first step was to conduct an analysis on the lecturers which concerned about the products they want to develop. Based on the results of the analysis, the lecturers were in dire need of an interactive physics learning media in the form of Web-Enhanced Course with Problem-Based Learning model (PBL) in the Basic Physics II subject which can minimize the duration of learning so that learning could be more effective and efficient. After that, the researchers analyzed the students' responses toward the developed product which mostly state that the developed product gave more benefits during the learning activities.

The preparation steps of the product development were done by deciding ideas, analyzing the material to be displayed, specifying the web system to be created (content material in the form of text, images, video learning, PhET simulations, and exercises), and determining the web hosting and domain.

The following are some displays of the developed product.

Table 3. The Display of Web-Enhanced Course with Problem-Based Learning model (PBL)

\begin{tabular}{|c|c|c|}
\hline No & Title & Display \\
\hline 1 & $\begin{array}{l}\text { Home Display of the } \\
\text { Website } \\
\text { (fisika -ril.web.id) }\end{array}$ & 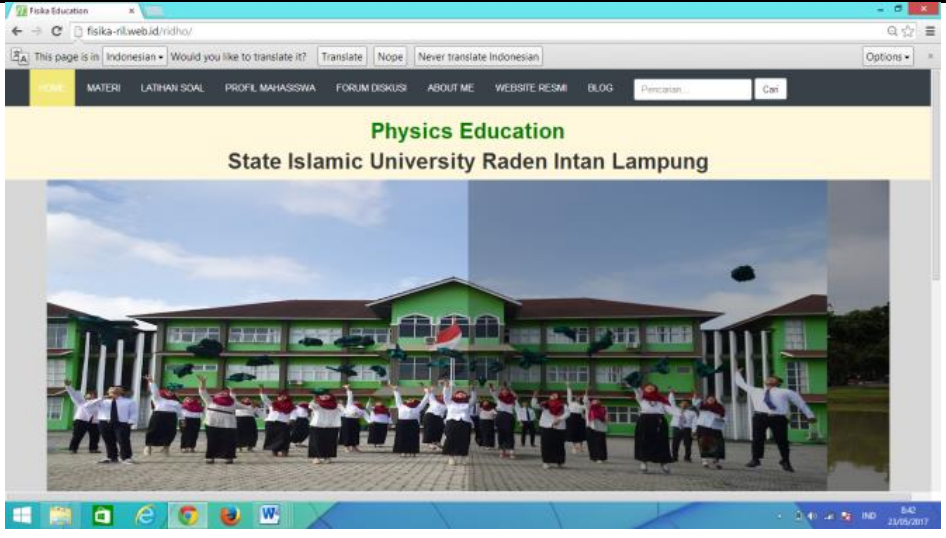 \\
\hline
\end{tabular}




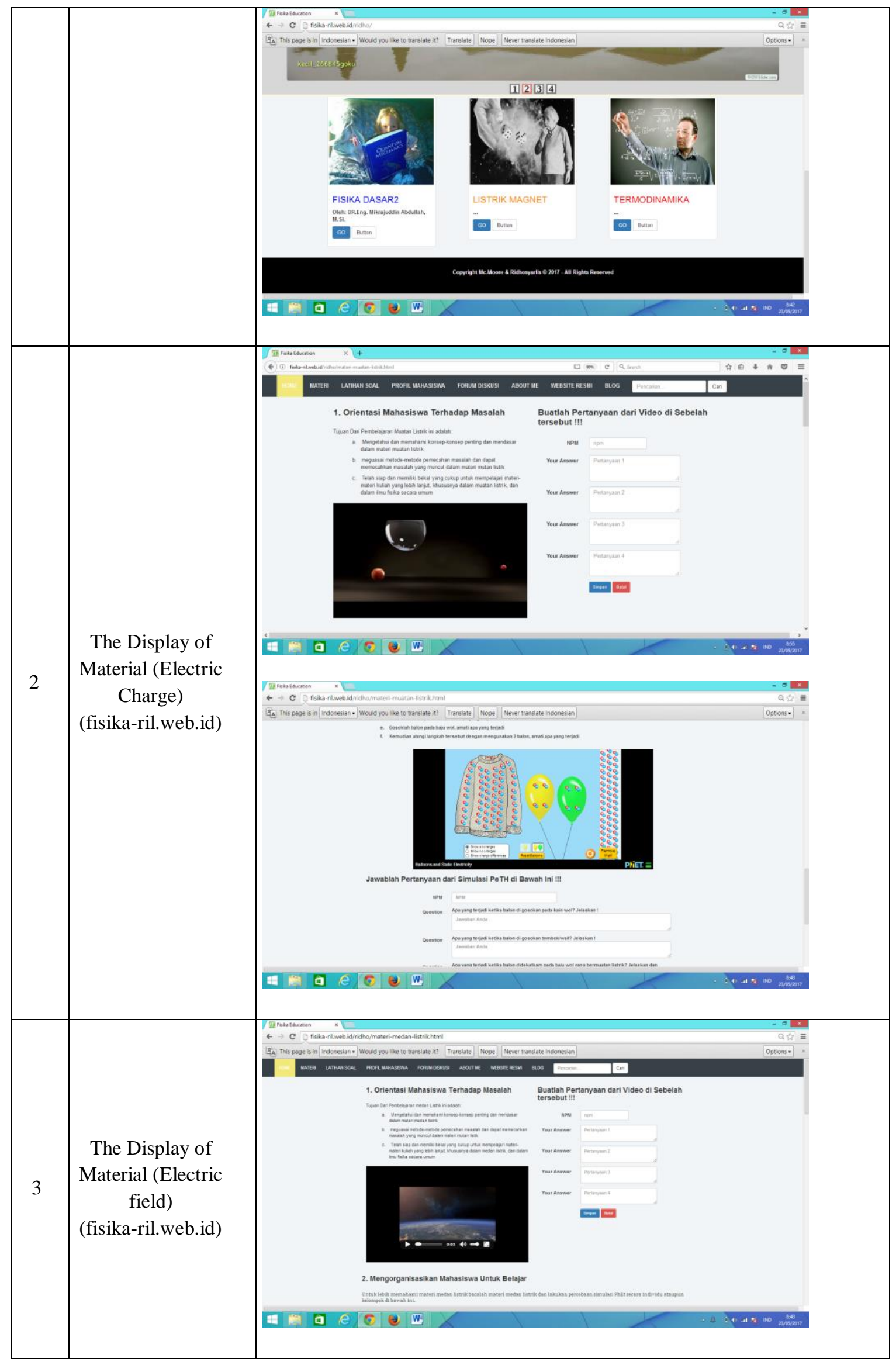




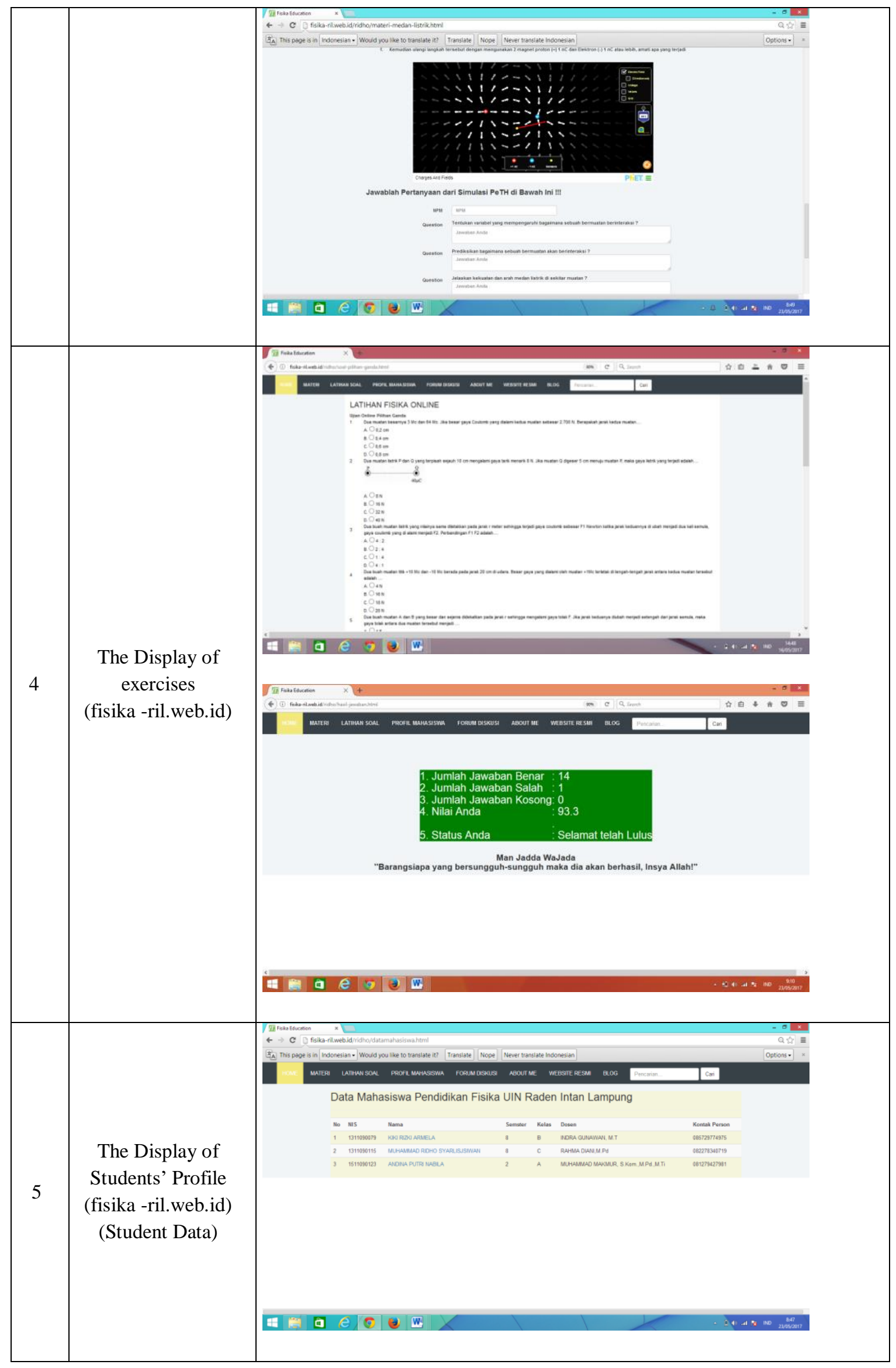




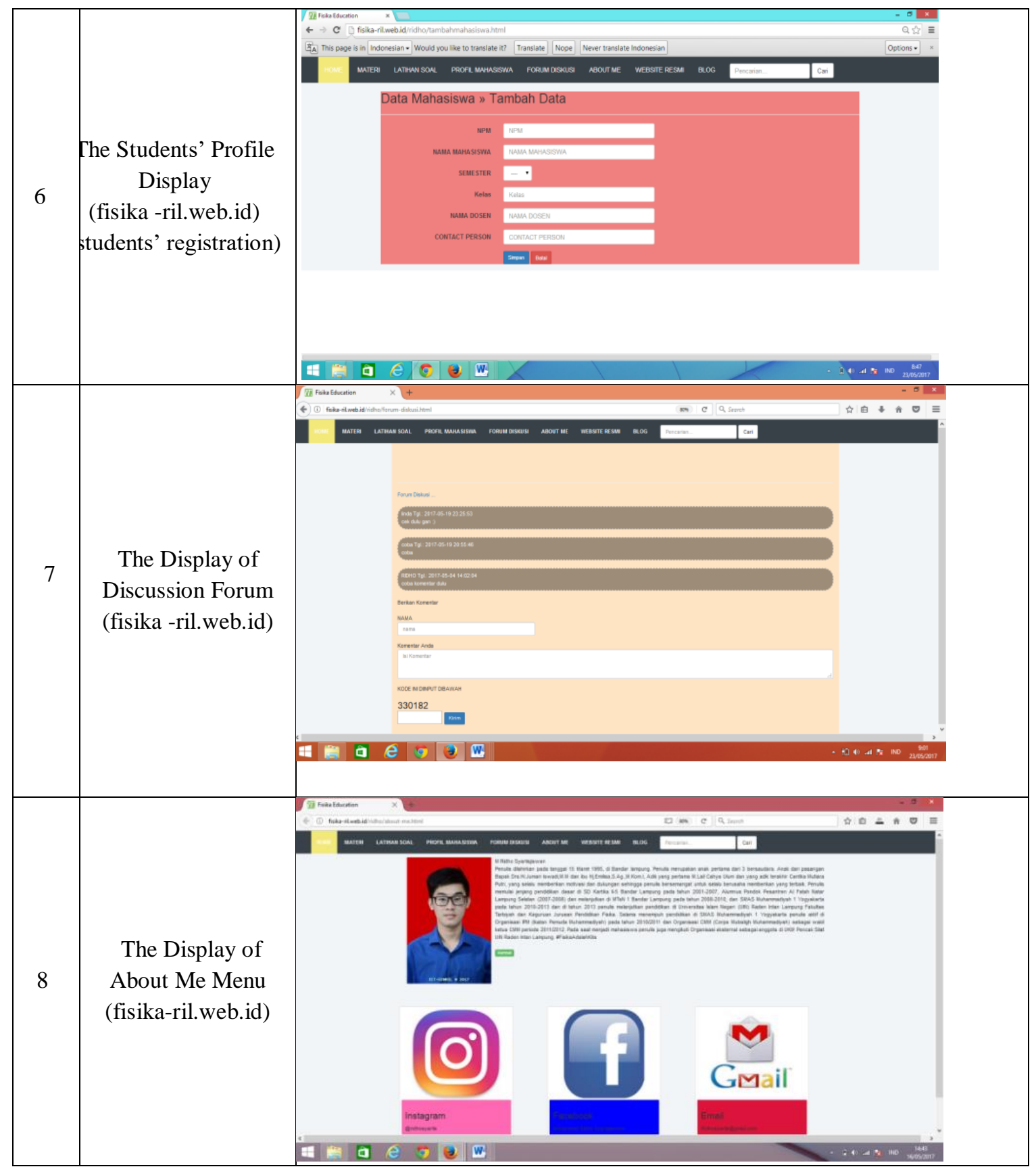

The developed product was validated by several experts before being tested in the field. Validation was carried out by 3 material experts, 3 media experts and 3 informatics experts.

a. Validation Results by Material Expert

The result of validation by material experts toward the product is presented in the following table.
Table 4. Validation Results by Material Expert No Aspect Assessment Feasibility

1 Quality of Content Percentage Material

\begin{tabular}{clc}
\hline 2 & Linguistic Aspects & $85 \%$ \\
\hline 3 & Material Implementation & $84.8 \%$ \\
\hline 4 & Visual Layout & $76.7 \%$ \\
\hline 5 & Audio Aspects & $88.9 \%$ \\
\hline 6 & Easiness of the Usage & $93.3 \%$ \\
\hline 7 & $\begin{array}{l}\text { Problem-Based Learning } \\
\text { Model }\end{array}$ & $82,7 \%$ \\
\hline
\end{tabular}


Based on the table. 4, it can be seen on the aspect of the quality of content material gained $82.5 \%$ of the feasibility percentage. The linguistic aspect gained $85 \%$ of the feasibility percentage. The material implementation aspect gained $84.8 \%$ of the feasibility percentage. The visual layout of the material aspect gained $76.7 \%$ of the feasibility percentage. The audio aspect gained $88.9 \%$ of the feasibility percentage. The easiness of the usage aspect gained $93.3 \%$ of the feasibility percentage, and the problembased learning model aspect gained $82.7 \%$ of the feasibility percentage. The average percentage from the material experts' assessment gained $84.83 \%$ of the feasibility percentage. The assessment result from the material experts was in the highly feasible category.

\section{b. Validation Results by Media Experts \\ The results of validation by media/design experts on the developed product is presented in the following table:}

Table 5. Validation Results by Media Experts

\begin{tabular}{lll}
\hline No & Aspects of Assessment & $\begin{array}{c}\text { Feasibility } \\
\text { Percentage }\end{array}$ \\
\hline 1 & Quality of Content & $86.7 \%$ \\
2 & Material & \\
3 & Linguistic Aspects & $82.2 \%$ \\
4 & Material Implementation & $80 \%$ \\
5 & Visual Layout & $81.7 \%$ \\
6 & Eudio Aspects & $83.3 \%$ \\
\hline & Easiness of the Usage & $76.7 \%$ \\
\hline
\end{tabular}

Based on the table. 5, it can be seen on the aspect of the quality of content material gained $86.7 \%$ of the feasibility percentage. The linguistic aspect gained $82.2 \%$ of the feasibility percentage. The material implementation aspect gained $80 \%$ of the feasibility percentage. The visual layout of the material aspect gained $81.7 \%$ of the feasibility percentage. The audio aspect gained $83.3 \%$ of the feasibility percentage. The easiness of the usage aspect gained $76.7 \%$ of the feasibility percentage. The average score from the media experts gained $81.76 \%$ of the feasibility percentage. So the result of the assessment by the media experts was in the highly feasible category.

c. Validation Results by Informatics Experts

The results of validation by informatics experts on the developed product is presented in the following table:

Table 6. Validation Results by Informatics Experts

\begin{tabular}{|c|c|c|}
\hline No & Aspect Assessment & $\begin{array}{l}\text { Feasibility } \\
\text { Percentage }\end{array}$ \\
\hline 1 & Content Quality & $80 \%$ \\
\hline 2 & Lay out & $82.2 \%$ \\
\hline 3 & Coloring & $86.7 \%$ \\
\hline 4 & Fonts & $91.1 \%$ \\
\hline 5 & $\begin{array}{l}\text { Images, Videos, and } \\
\text { PhET Simulations }\end{array}$ & $86.7 \%$ \\
\hline 6 & Icon & $82.2 \%$ \\
\hline 7 & Audio Quality & $86.7 \%$ \\
\hline 8 & Easiness of the Usage & $73.3 \%$ \\
\hline & Average & $\mathbf{8 3 . 6 1 \%}$ \\
\hline
\end{tabular}

Based on table 6 , it can be seen on the aspect of the quality of content material gained $80 \%$ of the feasibility percentage. The lay out aspect gained $82.2 \%$ of the feasibility percentage. The coloring aspect gained $86.7 \%$ of the feasibility percentage. The font aspect gained $91,1 \%$ of the feasibility percentage. The Images, Videos and PhET Simulations aspect gained $86.7 \%$ of the feasibility percentage. The icon aspect gained $82.2 \%$ of the feasibility percentage. The audio quality aspect gained $86.7 \%$ of the feasibility percentage, and The easiness of the usage aspect gained $73.3 \%$ of the feasibility percentage. The average score from the Informatics experts gained $83.61 \%$ of the feasibility percentage. So the result of the 
assessment by the informatics experts was in the highly feasible category.

\section{d. Product Testing}

The testing of the revised learning media was carried out in two places: first, to the two classes of the second semester students of the Physics Education Department UIN Raden Intan Lampung and one class of the second semester students of the Physics Education Department, University of Lampung. The testing was in the form of small-group testing and field-testing. The product testing was conducted during the learning process, after learning by using the interactive Physics learning media in the form of Web-Enhanced Course with Problem-Based Learning model (PBL) in the Basic Physics II subject. The students were asked to fill in the questionnaire.

Student questionnaire consisted of 3 aspects of assessment, namely aspects of content quality, aspects of media lay out, and aspects of technical quality. In smallgroup testing was conducted on the second semester students of the of Physics Education Department of UIN Raden Intan Lampung, the feasibility of the learning media gained $76.44 \%$ in the Feasible category. The data of the smallgroup testing can be seen in the following figure:

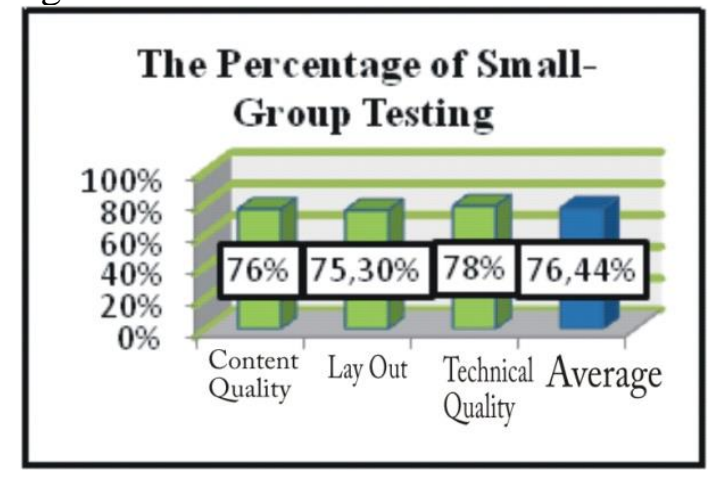

Figure 1. Small-Group Testing of Physics Education Department of UIN Raden Intan Lampung

Field-testing was conducted on the second semester students of the of Physics Education Department of UIN Raden Intan Lampung. The feasibility percentage gained was $83.45 \%$ in the highly feasible category. The field-testing was conducted on the second semester students of the Physics Education Department, the University of Lampung, the feasibility percentage gained was $81.38 \%$ in the highly feasible category. The combination of the percentage of feasibility gained from the two universities resulting in the average percentage of $82.34 \%$ in the highly feasible category. Data from the smallgroup testing of the two universities can be seen in the following figure:

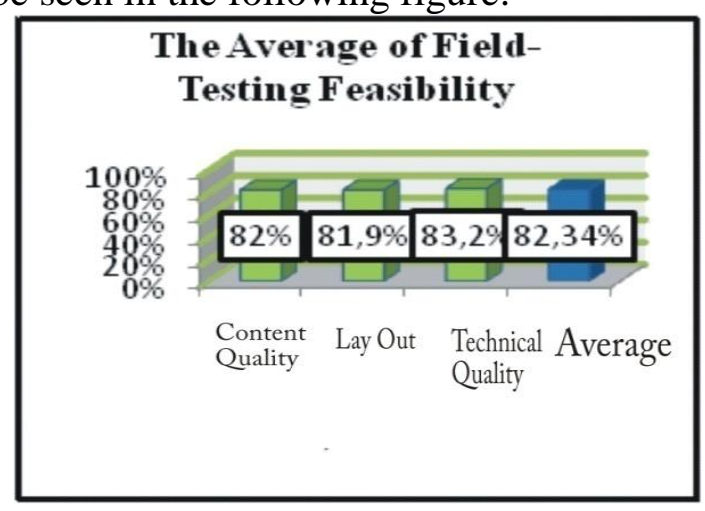

Figure 2. The Average Field-testing result of the Two Universities

Based on the stages carried out in this research, the developed learning media possesses a very good quality and is suitable to be used by students in the learning process especially for the second semester of the Physics Education Department. The interactive Physics learning media in the form of WebEnhanced Course with Problem-Based Learning model (PBL) shows that the material and practice questions have fulfilled the criteria as a good Physics learning media.

\section{CONCLUSION AND SUGGESTION Conclusion}

Based on the research, the following conclusions can be drawn.

1. The developed product is an interactive Physics learning media in the form of Web-Enhanced Course with ProblemBased Learning model (PBL) in the 
Basic Physics II subject that can be accessed online through the website: phys-ril.web.id. The features of the website are the collection of materials in the form of text, images, videos, PhET simulations, discussion forums, practice questions, and assessments. The interactive Physics learning media in the form of Web-Enhanced Course with Problem-Based Learning model (PBL) in the Basic Physics II subject can be applied in the learning process for the Physics Education Department students of UIN Raden Intan Lampung.

2. Validators Responses toward the interactive Physics learning media in the form of Web-Enhanced Course with Problem-Based Learning model (PBL) in the Basic Physics II subject were gained from material experts, media experts, and Informatics experts with ideal percentages of $84.83 \%$, $81.76 \%$, and $83.61 \%$.

3. The feasibility of the developed products in small-group testing and field-testing conducted at the Physics Education Department of UIN Raden Intan Lampung and the Physics Education Department of Lampung University gained a positive response. The ideal percentage gained from the two universities for both testings were $74.47 \%$ and $82.34 \%$. This result proves that the interactive Physics learning media in the form of Web-Enhanced Course with Problem-Based Learning model (PBL) is very effective, efficient, and feasible to be applied.

\section{Suggestion}

It is suggested for the interactive Physics learning media in the form of Web-Enhanced Course with ProblemBased Learning model (PBL) in the Basic Physics II subject to be developed further so that it can be utilized more optimally and the existing data can be accessed properly. It also needs to be developed for other physics subjects.

\section{REFERENCES}

Al-zindani, Aziz., \& A. majid bin. (1997). Mukzijat Al-Qur'an dan As-Sunnah Tentang IPTEK. Jakarta: Gema Insani Pers.

Alfath, S. N., Ellianawati, \& Sukisno, M. (2013). Pengembangan Media Blended Learning Berbasis Web. Unnes Physics Education Journal, 2(1), 1-6. Retrieved from http://journal.unnes.ac.id/sju/index.p $\mathrm{hp} /$ upej

Amri, I. (2014). Pengembangan Media Pembelajaran E-Learning Berbasis Web Untuk Mata Kuliah Pendahuluan Fisika Inti, (1), 25-35.

APJII. (2016). Penetrasi Pengguna Internet di Indonesia 2016. https://apjii.or.id/survei2016.

Arsi, F., \& Febrianti, K. V. (2014). Pengembangan Media Pembelajaran Fisika Berbasis Web untuk SMA Kelas X pada Pokok Bahasan Listrik Dinamis. In Prosiding Seminar Nasional Fisika dan Pendidikan Fisika, 5, 33-42.

Asyhari, A., \& Diani, R. (2017). Pembelajaran Fisika Berbasis Web Enhanced Course: Mengembangkan Web-logs Pembelajaran Fisika Dasar

1. Jurnal Inovasi Teknologi Pendidikan, 4(1), 13-25. https://doi.org/10.21831/jitp.v4i1.13 435.

Doyan, A., \& Sukmantara, I. K. Y. (2014). Pengembangan Web Intranet Fisika Untuk Meningkatkan Penguasaan Konsep dan Kemampuan Pemecahan Masalah Siswa SMK. Jurnal Pendidikan Fisika Indonesia, 10(2), 117-127. https://doi.org/10.15294/jpfi.v10i2.3 348.

Emzir. (2015). Metodologi Penelitian Pendidikan Kuantitatif dan Kualitatif. Jakarta: PT Raja Grafindo Persada.

Gunawan, I. (2014). Pengembangan Aplikasi Mobile Learning Fisika 
sebagai Media Pembelajaran Pendukung. Jurnal Ilmiah Pendidikan Fisika Al-Biruni, 3(1), 2. Habibi, G. A., \& Kurniawan, A. (2014). Pengembangan Media Pembelajaran Berbasis Web Untuk Mengoptimalkan Hasil Belajar Siswa Pada Mata Pelajaran Fisika Materi Keseimbangan Benda Tegar Kelas Xi Sma Antartika Sidoarjo. Universitas Negeri Surabaya, 75.

Hidayatullah, P., \& Kawistrara, J. K. (2017). Pemerograman WEB. Bandung: Informatika Bandung.

Irwandani, I. (2016). Potensi Media Dosial dalam Mempopulerkan Konten Sains Islam. Tadris: Jurnal Keguruan Dan Ilmu Tarbiyah, 1(2), 173-177.

Putri, A. C. (2015). Pengembangan Media Pembelajaran Fisika Berbasis WEB Untuk Meningkatakan Adversity Quotient Peserta Didik. In Prosiding Seminar Nasional Fisika.

S.Ramos, J. L., B.Dolipas, B., \& B.Villamor, B. (2013). High Order Thinking Skills and Academic Performance in Physics of College Students: A Regression Analysis. International Journal of Innovative Interdisciplinary Research, 4, 48-60.

Saregar, A. (2016). Pembelajaran Pengantar Fisika Kuantum dengan Memanfaatkan Media Phet Simulation dan LKM Melalui Pendekatan Saintifik: Dampak pada Minat dan Penguasaan Konsep Mahasiswa. Jurnal Ilmiah Pendidikan Fisika Al-Biruni, 5(1), 53-60.

https://doi.org/10.24042/jpifalbiruni. v5i1.105

Saregar, A., Latifah, S., \& Sari, M. (2016). Efektivitas Model Pembelajaran CUPS: Dampak terhadap Kemampuan Berpikir Tingkat Tinggi Peserta Didik Madrasah Aliyah Mathla'ul Anwar Gisting Lampung. Jurnal Ilmiah
Pendidikan Fisika Al-Biruni, 5(2), 233-243.

Saregar, A., \& Sunarno, W. (2013). Eksperimen dan Demonstrasi Diskusi menggunakan Multimedia Interaktif ditinjau dari Sikap Ilmiah dan Kemampuan Verbal Siswa. Jurnal Inkuiri, 2(2), 100-113.

Sugiono. (2013). Metode Penelitian Kuantitatif, kualitatif dan $R \& D$. Bandung: Alfabeta.

Sutedjo, B. (2002). E-Education Konsep, Teknologi dan Aplikasi Internet Pendidikan. Yogyakarta: Andi.

Ulya, S. H. N. U. N. (2013). Keefektifan Model Pembelajaran Guide Inquiry Berbasis Think Pair Share (TPS) dalam Meningkatkan Pemahaman Konsep Fisika Kelas XI SMA. Unnes Physics Education Journal, 2(2), 17-23. Retrieved from http://journal.unnes.ac.id/sju/index.p hp/upej.

Wahyudi, B. S. (2014). Pengembangan Bahan Ajar Berbasis Model Problem Based Learning Pada Pokok Bahasan Pencemaran Lingkungan Untuk Meningkatkan Hasil Belajar Siswa Kelas X Sma Negeri Grujugan Bondowoso. Jurnal Pendidikan Dan Pengajaran.

Wahyudi, I. (2017). Pengembangan Program Pembelajaran Fisika SMA Berbasis E-Learning dengan Schoology. Jurnal Ilmiah Pendidikan Fisika Al-Biruni, 6(2), 187-199.

https://doi.org/10.24042/jipfalbiruni. v6i2.1850.

Yuberti. (2015). Pandangan Islam Terhadap Perkembangan Teknologi Komunikasi dan Informasi. Jurnal Tekno-Pedagogi PPs Universitas Jambi. 